\title{
Genetic diversity of three European Veratrum species revealed by Amplified Fragment Length Polymorphism
}

\author{
Magdalena Szeliga*, Joanna Ciura \& Mirosław Tyrka
}

Department of Biotechnology and Bioinformatics, Faculty of Chemistry, Rzeszow University of Technology, Powstańców Warszawy 6, 35-959 Rzeszów, Poland

*corresponding author (e-mail: mszeliga@prz.edu.pl)

\begin{abstract}
Chemical and genetic characterization of Veratrum species deposited in European collections is important for genepool preservation and identification of populations with desired metabolic properties. Veratrum album, V. lobelianum and V. nigrum are native to Europe, and in Poland are ranked as rare or threatened. Genetic variation of European Veratrum species was characterized by Amplified Fragment Length Polymorphism (AFLP) markers. The accumulation of jervine as a representative of steroidal alkaloids was measured in seeds. Distribution of 380 markers generated from eight primer combinations was useful for studying genetic relationships among and within species in the Veratrum genus and the most divergent populations were identified. Genetic variation between 12 populations of Veratrum species supports the classification of $V$. lobelianum as a subspecies of $V$. album. However, the results need further validation on extended material. A higher genetic diversity (22.3\%) was observed between populations of $V$. nigrum as compared to $V$. album (14.5\%). Contents of jervine allowed for discrimination of the studied Veratrum species and can be used as a potential chemotaxonomic marker. The highest jervine levels were found in $V$. album. V. nigrum seeds had only trace amounts and no jervine was detected in seeds of V. lobelianum.
\end{abstract}

Key words: genetic variation, hellebore, jervine, Melanthiaceae, molecular markers

\section{Introduction}

The Veratrum genus (Liliales, Melanthiaceae) comprises 17-45 species distributed over a wide range of habitats of the Northern Hemisphere (Zomlefer et al. 2003; Treier \& Müller-Schärer 2011). Veratrum album L., Veratrum lobelianum Bernh. and Veratrum nigrum L. are native to Europe. Only a few isolated populations of these species are present in Poland and ranked as rare or threatened (Allen et al. 2014). Veratrum album sensu lato is a complex of subspecies $V$. album ssp. album and $V$. album ssp. lobelianum (Schaffner et al. 2001) sometimes considered as separate species (Zomlefer $e t$ al. 2003). Plants of Veratrum are a rich source of unique bioactive steroidal alkaloids (Chandler \& McDougal 2014). Quantitative and qualitative variations in the metabolic profile and pharmacological properties are affected by environmental factors and genetic diversity present in natural populations (Li et al. 2015).

There are three subtypes of Veratrum-type alkaloids including cevanine, veratramine and jervine that are divided according to structural features (Li et al. 2006). These steroidal alkaloids are well known for their pharmacological activities, including hypotensive, antithrombotic and antitumour functions (Tang et al. 2008a; Ivanova et al. 2011). In particular, cyclopamine showed antitumour activity and induced apoptosis using the mechanism of inhibition of the hedgehog pathway in a subset of the pancreatic cancer cell line (Thayer et al. 2003). Due to low cyclopamine concentration in Veratrum plants (about $0.01 \%$ ), we focussed our attention on jervine that was present in higher concentrations $(0.1 \%)$ and can be transformed to cyclopamine by Wolff-Kishner reduction with Huang-Minlon modification (Tang et al. 2008b). Jervine displays strong antifungal activities against the phytopathogenic Phytophthora capsici (Li et al. 2006).

Medical plants from Melanthiaceae are interesting specimens for genetic diversity studies ( $\mathrm{Li}$ et al. 2011; Treier \& Müller-Schärer 2011). For genetic characteristics targeting taxonomic questions, variation in cpDNA and the internal transcribed spacer (ITS) 
region of rDNA are standard (Zomlefer et al. 2003; Griffin \& Barrett 2004; Liao et al. 2007). Systems targeting conservative regions of DNA were ideal for separating evolutionary different populations of Trillium grandiflorum and $V$. album ssp. oxysepalum (Griffin \& Barrett 2004; Kikuchi et al. 2010). However, to study genetic diversity within and between natural populations, amplified fragment length polymorphism (AFLP) system is a method of choice (Guthridge et al. 2001; Quagliaro et al. 2001; Tang et al. 2003; Llanes et al. 2011). This DNA fingerprinting technique targets multiple loci, generates dominant markers for wholegenome screening and has higher reproducibility, resolution, and sensitivity compared to random amplified polymorphic DNA (RAPD) and inter simple sequence repeats (ISSRs) methods (Vos et al. 1995; Blears et al. 1998).

Various genetic marker systems have been used to characterize variation in the Veratrum genus, including RAPD (Kleijn \& Steinger 2002), AFLP (Treier \& Müller-Schärer 2011) and simple sequence repeats (Kato et al. 2008; Kikuchi \& Maki 2011). AFLP studies of 40 European natural populations of $V$. album revealed eastwest direction in the genetic structure and suggested ancient migration from Asia (Treier \& Müller-Schärer 2011).

So far, genetic diversity between and within European accessions of $V$. nigrum, V. album and $V$. lobelianum has not been investigated with AFLP markers. Chemical and genetic characterization of Veratrum species deposited in European collections generates new information useful both for genepool preservation and for identification of populations with desired metabolic properties. Jervine content was determined to preliminary test the suitability of this genera-specific steroid alkaloid as a potential chemotaxonomic marker.

\section{Materials and methods}

\subsection{Plant materials}

Plant collection consisted of six populations of $V$. nigrum, five populations of $V$. album and a single population of $V$. lobelianum maintained in botanical gardens across seven European countries (Table 1). Seeds from population $\mathrm{N} 5$ ( $V$. nigrum) were germinated and plants were maintained in vitro, then lyophilized prior to DNA extraction. Seeds of the remaining families had reduced viability and, therefore, were used directly (3-7 random seeds) for DNA isolation. The names of genus and species follow Zomlefer et al. (2003).

\subsection{DNA extraction and AFLP analysis}

Total plant genomic DNA was extracted from seeds or lyophilized plants using a method developed by Milligan (1992). The DNA was quantified using agarose gel electrophoresis and diluted to a concentration of $200 \mathrm{ng} \cdot \mathrm{mL}^{-1}$ prior to AFLP analysis. The AFLP analysis was carried out according to the methods of Thomas et al. (1995). Genomic DNA was digested with MseI and PstI restriction enzymes (5 U each) in Tango buffer (33 $\mathrm{mM}$ Tris-acetate, $\mathrm{pH} 7.9$ at $37^{\circ} \mathrm{C} ; 10 \mathrm{mM}$ magnesium acetate; $66 \mathrm{mM}$ potassium acetate; $0.1 \mathrm{mg} / \mathrm{ml} \mathrm{BSA}$ ) for $90 \mathrm{~min}$ at $65^{\circ} \mathrm{C}$ and $60 \mathrm{~min}$ at $37^{\circ} \mathrm{C}$, respectively. The enzymes were subsequently heat inactivated at $80^{\circ} \mathrm{C}$ for $20 \mathrm{~min}$ and the products ligated with MseI and Pst I adapters overnight at $37^{\circ} \mathrm{C}$ to generate template DNA for amplification. DNA was then purified by ethanol precipitation and dissolved in $20 \mu \mathrm{L}$ of water. Non-selective (NS) amplification $\left(30\right.$ cycles of $30 \mathrm{~s}$ at $94^{\circ} \mathrm{C}, 30 \mathrm{~s}$ at $56^{\circ} \mathrm{C}$ and $60 \mathrm{~s}$ at $72^{\circ} \mathrm{C}$ ) was conducted using primers complementary to MseI and PstI adaptors without selective nucleotides (5'-GATGAGTCCTGAGTAA-3'

Table 1. Populations of Veratrum species used for genetic and chemical analyses

\begin{tabular}{|c|c|c|c|c|}
\hline Acronym & Species & Sampling locality & Source of material & $\begin{array}{l}\text { Number } \\
\text { of plants }\end{array}$ \\
\hline N1 & V. nigrum & Nowy Sącz, POL & Private garden & 3 \\
\hline $\mathrm{N} 2$ & V. nigrum & Ljubljana, SVN & University Botanic Gardens & 7 \\
\hline N3 & V. nigrum & Bayreuth, DEU & Ecological Botanical Gardens & 5 \\
\hline N4 & V. nigrum & Romsey, GBR & Sir Harold Hillier Gardens & 5 \\
\hline N5 & V. nigrum & Brno, CZE & Masaryk University Botanic Garden & 6 \\
\hline N6 & V. nigrum & Yoskar-Ola, RUS & Botanical Garden of the Technological State University & 5 \\
\hline L1 & V. lobelianum & Ljubljana, SVN & University Botanic Gardens & 6 \\
\hline A1 & V. album & Bayreuth, DEU & Ecological Botanical Gardens & 5 \\
\hline A2 & V. album & Bolestraszyce, POL & Arboretum and Institute of Physiography & 6 \\
\hline A3 & V. album & Bonn, DEU & University Botanic Gardens & 6 \\
\hline A4 & V. album & Nancy, FRA & Conservatory and Botanical Gardens & 4 \\
\hline A5 & V. album & High Tatra Mts, POL & Collecting & 6 \\
\hline
\end{tabular}


and 5'-GACTGCGTACATGCAG-3', respectively). The diluted PCR products of the NS amplification were selectively amplified with eight combinations of $\mathrm{MseI}$ primers (M43, M47, M48, M50, M59) and PstI primers (P4, P12, P15, P16, P18, P26, P34), each containing three selective nucleotides at the 3'-end. Symbols of the selective primers are in accordance with the KeyGene standard list for AFLP primer nomenclature. Selective amplification was accomplished with a touchdown thermal cycle, as follows: 7 cycles at $94^{\circ} \mathrm{C}$ for $60 \mathrm{~s}, 65^{\circ} \mathrm{C}$ $\left(-1^{\circ} \mathrm{C}\right.$ per cycle) for $60 \mathrm{~s}, 72^{\circ} \mathrm{C}$ for $120 \mathrm{~s}$, followed by 29 cycles at $94^{\circ} \mathrm{C}$ for $60 \mathrm{~s}, 56^{\circ} \mathrm{C}$ for $60 \mathrm{~s}$ and $72^{\circ} \mathrm{C}$ for 120 $\mathrm{s}$ and a final elongation at $72^{\circ} \mathrm{C}$ for $10 \mathrm{~min}$. The PCR products were run on a $5 \%$ polyacrylamide sequencing gel and detected with silver staining (Fiust et al. 2015).

\subsection{Extraction and quantitative analysis of jervine}

Jervine was extracted from samples that were ultrasonicated with chloroform and ammonia hydroxide (20:3) for $40 \mathrm{~min}$ at room temperature. The extracts were filtered and evaporated to dryness under reduced pressure. The residue was dissolved in methanol (Wang et al. 2008). The amount of jervine in extracts was determined by ultra performance liquid chromatography (UPLC, Shimadzu) coupled with QTRAP 4500 mass spectrometry (AB Sciex) with triple quadrupole. Analytical separation was carried out using the UPLC system with a Kinetex XB - C18 LC column (50 mm x $2.1 \mathrm{~mm}$ I.D., $1.7 \mu \mathrm{m})$. The column temperature was set at $40^{\circ} \mathrm{C}$. A binary gradient elution system consisted of acetonitrile (a) and water ( $0.01 \%$ formic acid) (b). Separation was achieved using the following gradient program: $0-5 \mathrm{~min}$, linear gradient $(0-100 \%$ a). The flow rate was adjusted to $0.5 \mathrm{~mL} \cdot \mathrm{min}^{-1}$ and an injection volume of $2 \mu \mathrm{L}$. Compounds were quantitated with an electrospray ion source in the positive ion mode (ESI-MS), under these conditions: temperature $600^{\circ} \mathrm{C}$, spray voltage: $+5000 \mathrm{~V}$. The fragmentation transitions were for multiple reaction monitoring (MRM). MRM was performed with $50 \mathrm{~ms}$ dwell time per channel. The following transitions were detected: $\mathrm{m} / \mathrm{z} 425.89 / 313.10$ Da and 425.89/114.0 Da for jervine (Tang et al. 2008b; Grobosch et al. 2008).

\subsection{Data analysis}

For the diversity analysis, the amplification products were scored for the presence (1) and absence (0) of bands to form a binary matrix. These data were used to calculate polymorphism information, including the number of polymorphic/species-specific fragments and PIC (polymorphism information content) according to Roldan-Ruiz et al. (2000). The AFLPsurv 1.0 (Vekemans et al. 2002) and Popgene ver. 1.32 (Yeh \& Boyle 1997) were used to evaluate basic parameters for the population genetic structure, including $\mathrm{Ht}$ - total gene diversity, $\mathrm{Hw}$ - gene diversity within populations, $\mathrm{Hb}$ - genetic differentiation among populations and Fst - Wright's fixation index (Lynch \& Milligan 1994). The relationships between individuals were visualised in TreeView 1.6.6 (Page 1996) as a dendrogram constructed using the unweighted pair-group method with arithmetic averages (UPGMA) method based on Nei's genetic distances (Nei 1972) computed in PHYLIP (Felsenstein 1989). PAST ver. 2.07 software (Hammer et al. 2001) and STRUCTURE v.2.3 (Pritchard et al. 2000) were used for principal coordinate analysis ( $\mathrm{PCoA})$ based on correlation matrix, and to discern populations. The package of STATISTICA v.10 was used for analysis of variance (ANOVA).

\section{Results}

\subsection{Amplified fragment length polymorphism (AFLP) analysis}

The genetic diversity among and within $V$. nigrum, $V$. album, and $V$. lobelianum represented respectively by 6,5 , and single populations from European collections was analysed using the AFLP method. Eight random combinations of selective primers resulted in 380 markers,

Table 2. Combinations of selective primers and obtained polymorphisms. Species-specific markers were identified for Veratrum nigrum (N) and V.album (A)

\begin{tabular}{ccccc}
\hline \multirow{2}{*}{ Primers } & \multicolumn{3}{c}{ Number of fragments } & \multirow{2}{*}{ PIC } \\
\cline { 2 - 4 } & Total & Polymorphic & Species specific & \\
\hline P16+M43 & 26 & 25 & $1(\mathrm{~A})$ & 0.329 \\
P18+M48 & 39 & 37 & 0 & 0.278 \\
P4+M50 & 58 & 53 & $2(\mathrm{~A})$ & 0.249 \\
P12+M47 & 50 & 49 & $1(\mathrm{~N})$ & 0.274 \\
P26+M59 & 51 & 50 & 0 & 0.235 \\
P15+M59 & 69 & 67 & $1(\mathrm{~N})$ & 0.246 \\
P16+M50 & 49 & 48 & 0 & 0.272 \\
P34+M48 & 38 & 37 & 0 & 0.195 \\
\hline
\end{tabular}


including $366(96.32 \%)$ that were polymorphic (Table 2). The average number of markers per primer set was 47.5 and varied from $26(\mathrm{P} 16+\mathrm{M} 43)$ to $69(\mathrm{P} 15+\mathrm{M} 59)$. The average number of polymorphic fragments per primer combination was 45.8 and the percentage of polymorphic bands oscillated in the narrow range from $91.38 \%$ (P4+M50) to $98.04 \%$ (P26+M59). The polymorphism information content (PIC) parameters identified the most informative markers and showed the distribution of identified polymorphisms. The mean (PIC) values for primer combinations ranged from 0.195 to 0.329 (Table 2).

\subsection{Genetic diversity}

Genetic relationships among 12 populations representing three species were analysed using allele frequencies and Nei's distances. Clustering of the populations revealed two main genotypic groups (Fig. 1). The first group comprised the six populations of $V$. nigrum, while the second cluster comprised $V$. album and V. lobelianum. Due to the genetic structure of these populations and the resolution of two distinct clusters, the data were split into $V$. album and $V$. nigrum sets for further population analyses.

Out of the 380 polymorphic fragments identified in the whole set of genotypes, more polymorphic fragments were found in V. album genotypes (285; $75.0 \%$ ) when compared to $V$. nigrum (253; 66.6\%). Nei's gene diversity $(\mathrm{He})$ in $V$. album populations $(0.176)$ was higher than that for $V$. nigrum (0.161). We identified 127 markers present only in populations of $V$. album (including $V$. lobelianum), and three alleles were fixed in all these populations and absent in V. nigrum. 88 markers

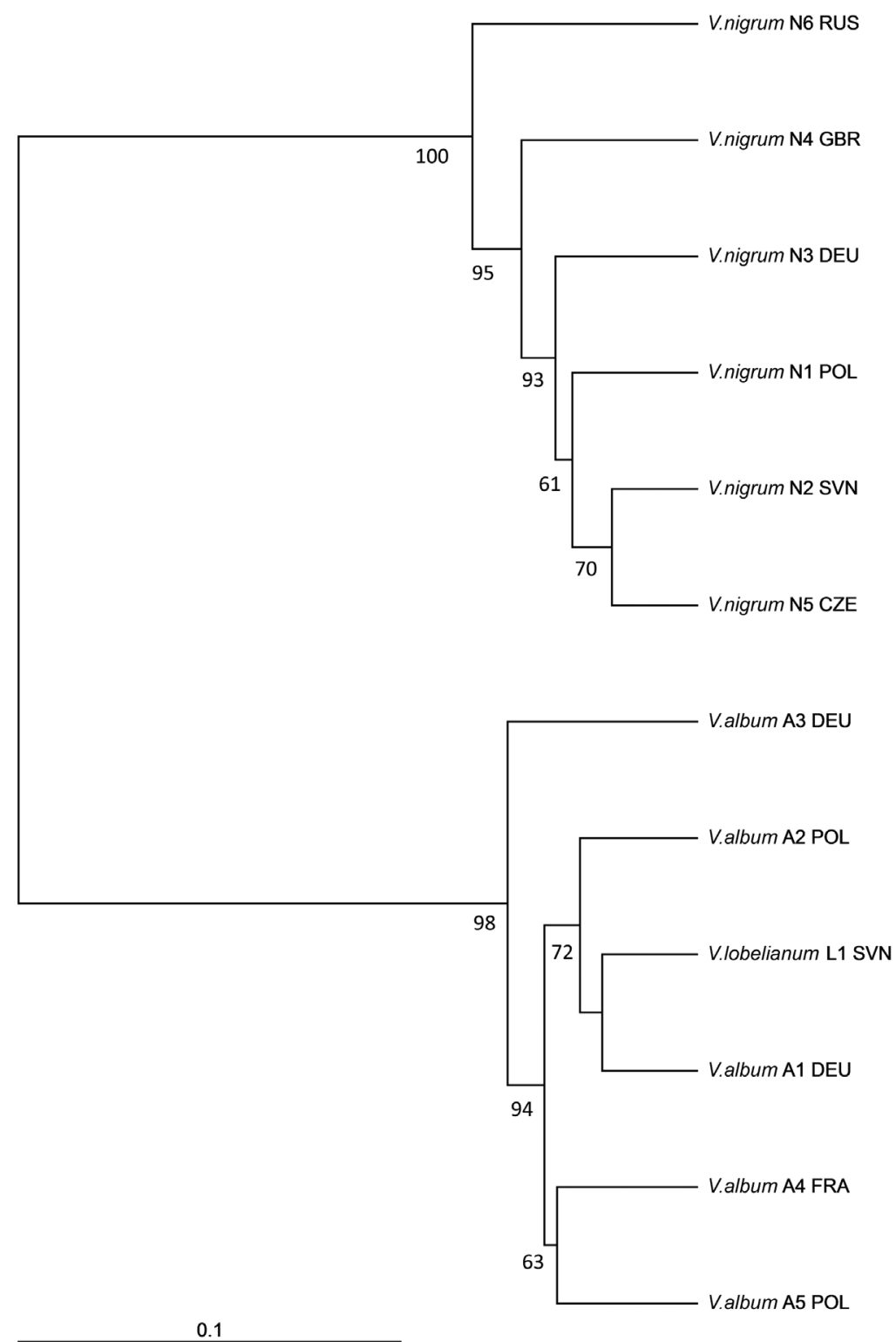

Fig. 1. Unweighted pair group method with arithmetic mean (UPGMA) dendrogram for 12 populations of Veratrum spp. based on Nei's genetic distances established for allele frequencies in 380 loci. Values on nodes represent the significance of the cluster for 100 bootstraps 
a

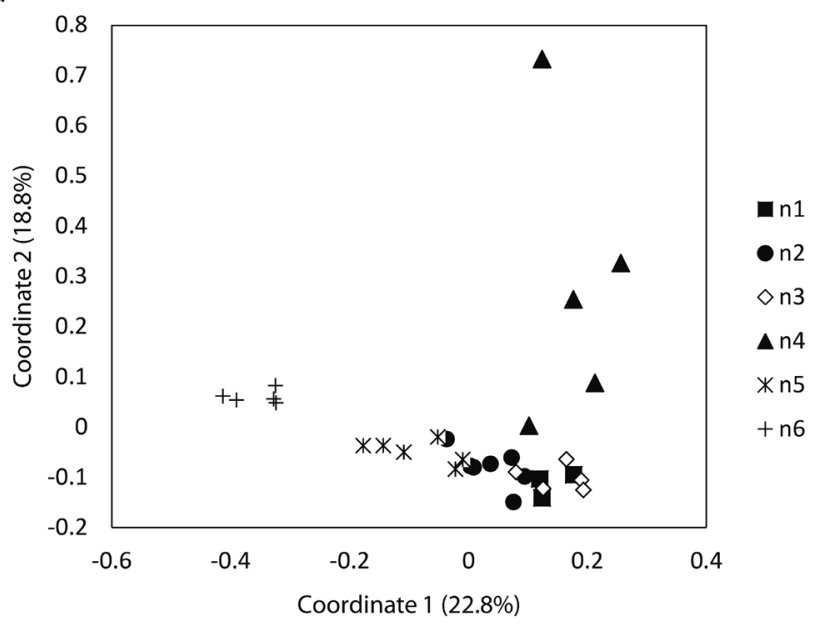

b

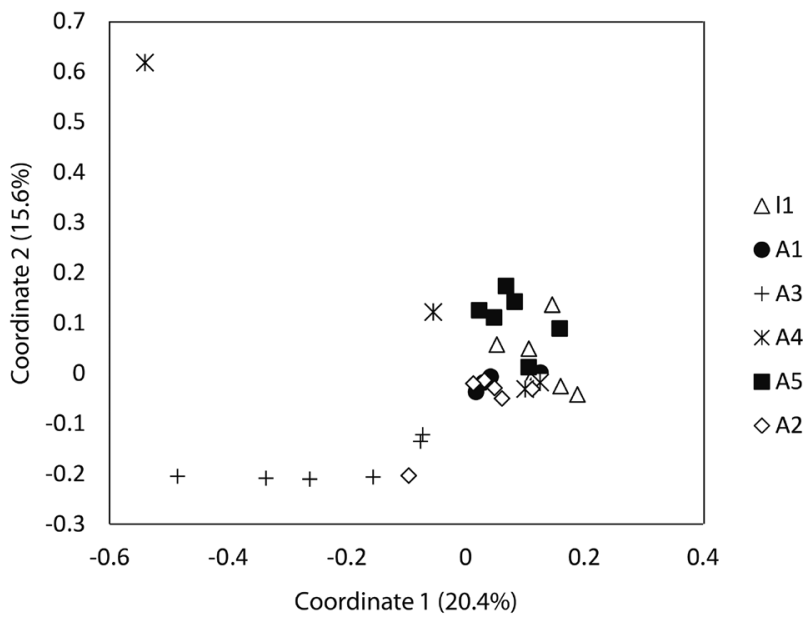

Fig. 2. Distribution of individuals in six populations of $V$. nigrum (a) and six populations of $V$. album, including $V$. lobelianum (b) across the two first principal coordinates were detected only in $V$. nigrum and two markers were present in all genotypes of $V$. nigrum and absent in the $V$. album gene pool. High bootstrap values indicate that the resolution was sufficient to discern groups at a statistically significant level.

The genotypes of $V$. album and $V$. nigrum were spread across the two first principal components (Fig. 2) accounting for $36.0 \%$ and $41.6 \%$ of the overall variation, respectively. Populations of $V$. nigrum from the United Kingdom (N4) and Russia (N6) are separated from the remaining populations from central and eastern Europe on the second and first coordinates (Fig. 2a). Populations of $V$. album formed two groups, with a German population (A3) isolated from the main gene pool (Fig. 2b). Analysis with STRUCTURE software confirmed the significance of population structure within $V$. album and $V$. nigrum, with the two and three subpopulations discerned, respectively.

The total gene diversity of $V$. nigrum $(\mathrm{Ht}=0.179)$ can be divided into variation deposited within $(\mathrm{Hw}=0.139$, $77.7 \%)$ and between populations $(\mathrm{Hb}=0.040,22.3 \%)$. Majority of the genetic diversity $(\mathrm{Ht}=0.197)$ in V. album was assigned to variation within populations $(\mathrm{Hw}=$ $0.168 ; 85.5 \%$ ). Wright's fixation index (Fst) was higher for $V$. nigrum (0.225) than for $V$. album (0.115), which confirmed that the total gene diversity in $V$. nigrum was shaped more by variation among populations.

\subsection{Content of jervine}

The mean content of jervine was determined in seeds of 10 populations by the UPLC-MS method. ANOVA revealed that the jervine content varied between species and populations $(\mathrm{p}<0.0001)$. The highest average

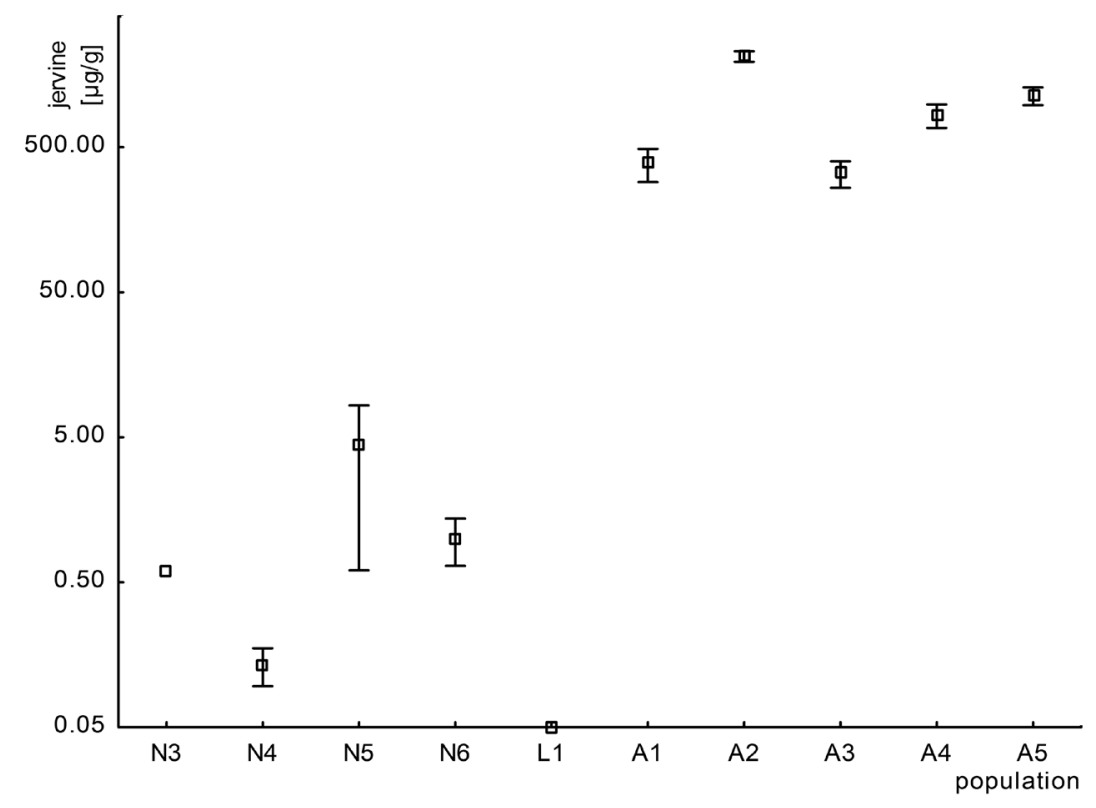

Fig. 3. Mean and standard error of jervine content in the seeds of Veratrum nigrum (N3-N6), V. lobelianum (L1) and V. album (A1-A5) 
Table 3. Jervine content $\left[\mu \mathrm{g} \cdot \mathrm{g}^{-1}\right]$ in the studied populations of Veratrum album, $V$. lobelianum, and $V$. nigrum

\begin{tabular}{lcccc}
\hline \multirow{2}{*}{ Species } & \multirow{2}{*}{\begin{tabular}{c} 
No. of \\
\cline { 3 - 5 }
\end{tabular}} & populations & mean $\pm \mathrm{SD}$ & Mervine content $\left[\mu \mathrm{g} \cdot \mathrm{g}^{-1}\right]$ \\
\hline V. nigrum & 4 & $1.74 \pm 3.69$ & 0.09 & Max \\
V. lobelianum & 1 & $0.00 \pm 0.00$ & 0.00 & 12.14 \\
V.album & 5 & $952.02 \pm 686.06$ & 210.00 & 0.00 \\
\hline
\end{tabular}

concentration of jervine $\left(952.02 \mu \mathrm{g} \cdot \mathrm{g}^{-1}\right)$ was found in $V$. album, and its content varied by more than 10 -fold between populations (Fig. 3, Table 3). More than 500 times less jervine was detected in seeds of $V$. nigrum $\left(1.74 \mu \mathrm{g} \cdot \mathrm{g}^{-1}\right)$. No jervine was detected in seeds of the single population of $V$. lobelianum.

\section{Discussion}

The AFLP technique provides an efficient and reproducible method for the simultaneous screening of multiple loci. In comparison with other fingerprinting techniques, it generates a large number of informative markers scattered across the genome (Magdy et al. 2016). In Veratrum album and other medicinal plants (Ypsilandra thibetica, Tribulus terrestris, Fritillaria sp.) the AFLP method generated from 69.9 to 147.8 bands per primer combination (Sarwat et al. 2008; Li et al. 2011; Treier \& Müller-Schärer 2011; Metin et al. 2013). In our studies, on average, 47.5 markers per randomly selected primer set were scored. The efficiency of AFLP measured as the number of bands per primers combination may be compromised by several factors, such as quality control of the AFLP procedures (contamination), properties of primers (preselection, number of selective bases), combination of restriction enzymes, method of detection, and genetic variation deposited in analyzed samples (Pompanon et al. 2005).

According to taxonomic classification, the Veratrum genus in Eurasia is divided into two sections Alboveratrum (e.g. V. album) and Fuscoveratrum (e.g. Veratrum nigrum L.). Veratrum album is separated into two subspecies, $V$. album ssp. album (central- and southEuropean distribution) and V. album ssp. lobelianum (Euro-Siberian distribution) but this distinction is often ignored (Schaffner et al. 2001). Furthermore, variation of chloroplast DNA (cpDNA) and ITS sequences supports the above division, with $V$. lobelianum as separate species (Liao et al. 2007; Kikuchi et al. 2010). Results of the AFLP analysis (Fig. 1) are consistent with discerning of sections, but variation in random DNA fragments indicates that $V$. lobelianum is not significantly different from $V$. album.

Recent AFLP studies revealed that $77-85 \%$ and $91-94 \%$ of genetic diversity was allocated within populations of $V$. album or $V$. album ssp. oxysepalum, respectively (Kikuchi et al. 2010; Treier \& MüllerSchärer 2011; Kikuchi et al. 2013). In the six European populations of $V$. album, we found a similar level of variation $(85.5 \%)$, and we identified population $\mathrm{A} 3$ that represents unique genetic characteristics. Compared to $V$. album, the variation within populations of $V$. nigrum was lower (77.7\%). This was confirmed by identification of the two subpopulations (N6 and N4) and higher Wright's fixation index. Our results are also consistent with high intraspecific variation previously reported for ITS sequences of $V$. nigrum (Liao et al. 2007). Genetically well diversified populations representing high variation may be preferred for characterizing genomes and transcriptomes.

The Veratrum genus is a source of steroidal alkaloids that have high anticancer activity and show healthbeneficial effects (Li et al. 2012). The Veratrum species characterized in this study displayed great variation in the content of jervine. The concentration of jervine varied significantly between populations of $V$. nigrum and $V$. album. Only trace amounts of jervine were found in seeds of $V$. nigrum, and no jervine was detected in seeds of $V$. lobelianum; however, this finding needs confirmation on extended materials. Although metabolic profiles are often affected by environmental factors and vary during plant development (Kleijn \& Steinger 2002), jervine content seems to be a promising chemotaxonomic marker. In spite of high interspecific variation, the concentration of this metabolite provides distinct ranges characteristic for the three tested species of Veratrum. Additionally, chemical profiling can be used to identify genotypes with target metabolic potential, and further genetic testing leading to mapping of loci involved in the biosynthesis of valuable metabolites.

\section{Conclusions}

Genetic variation of European Veratrum species was characterized by AFLP markers and the contents of genera-specific steroid alkaloid (jervine) was determined. The AFLP method was useful for studying the genetic relationships among and within species in the Veratrum genus and the most divergent populations 
were identified. Genetic variation between 12 populations of Veratrum species supports the classification of Veratrum lobelianum as a subspecies of V. album. However, the obtained results need further validation on extended material. Content of jervine used as a potential chemotaxonomic marker allowed for discrimination the studied Veratrum species.

\section{References}

Allen D., Bilz M., Leaman D. J., Miller R. M., Timoshyna A. \& Window J. 2014. European Red List of Medicinal Plants. ix +61 pp. Publications Office of the European Union, Luxembourg.

Blears M., De Grandis S., Lee H. \& Trevors J. T. 1998. Amplified fragment length polymorphism (AFLP): a review of the procedure and its applications. J Ind Microbiol Biotechnol 21: 99-114. http://dx.doi. org/10.1038/sj.jim.2900537

Chandler C. M. \& McDougal O. M. 2014. Medicinal history of North American Veratrum. Phytochem Rev 13: 671694. http://dx.doi.org/10.1007/s11101-013-9328-y

Felsenstein J. 1989. PHYLIP - Phylogeny Inference Package (Version 3.2). Cladistics 5: 164-166.

Fiust A., Rapacz M., WójciK-JAGŁa M. \& Tyrka M. 2015. Development of DArT-based PCR markers for selecting drought-tolerant spring barley. J Appl Genet 56: 299309. http://dx.doi.org/10.1007/s13353-015-0273-x

Griffin S. R. \& Barrett S. C. 2004. Post-glacial history of Trillium grandiflorum (Melanthiaceae) in eastern North America: Inferences from phylogeography. Am J Bot 91: 465-473. http://dx.doi.org/10.3732/ ajb.91.3.465

Grobosch T., Binscheck T., Martens F. \& Lampe D. 2008. Accidental intoxication with Veratrum album. J Anal Toxicol 32: 768-773. http://dx.doi.org/10.1093/ jat/32.9.768

Guthridge K. M., Dupal M. P., Kölliker R., Jones E. S., SMith K. F. \& Forster J. W. 2001. AFLP analysis of genetic diversity within and between populations of perennial ryegrass (Lolium perenne L.). Euphytica 122: 191-201.

Hammer Ø., Harper D. A. T. \& Ryan P. D. 2001. PAST: Paleontological Statistics Software Package for Education and Data Analysis. Palaeontol Electronica 4: 9.

Ivanova A., Serly J., Christov V., Stamboliyska B. \& Molnar J. 2011. Alkaloids derived from genus Veratrum and Peganum of Mongolian origin as multidrug resistance inhibitors of cancer cells. Fitoterapia 82: 570-575. http://dx.doi.org/10.1016/j.fitote.2011.01.015

Kato Y., Araki K., Kubota S. \& Ohara M. 2008. Development of microsatellite markers in a large perennial herb, Veratrum album subsp. oxysepalum. Mol Ecol Resour 8: 996-997.

KIKUCHI R. \& MAKI M. 2011. Characterization of polymorphic microsatellite markers isolated from the relict perennial Veratrum stamineum var. micranthum Satake (Melanthiaceae). Conserv Genet Resour 3: 507-509. http://dx.doi.org/10.1007/s12686-011-9390-y

Kikuchi R., Jae-Hong P., Takahashi H. \& MaKi M. 2010. Disjunct distribution of chloroplast DNA haplotypes in the understory perennial Veratrum album ssp. oxyse- palum (Melanthiaceae) in Japan as a result of ancient introgression. New Phytol. 188:879-891.

Kikuchi R., PAK J. H., TAKahashi H. \& MaKi M. 2013. Pattern of population genetic structure revealed by nuclear simple sequence repeat markers in the understory perennial Veratrum album ssp. oxysepalum (Melanthiaceae) with a disjunct pattern of chloroplast DNA haplotypes. Biol J Linn Soc 108: 278-293.

KLeijn D. \& Steinger T. 2002. Contrasting effects of erazing and hay cutting on the spatial and genetic population structure of Veratrum album, an unpalatable, longlived, clonal plant species. J Ecol 90: 360-370. http:// dx.doi.org/10.1046/j.1365-2745.2001.00676.x

Li D., BALdwin I. T. \& GAQUEREL E. 2015. Navigating natural variation in herbivory-induced secondary metabolism in coyote tobacco populations using MS/MS structural analysis. Proc Natl Acad Sci 112: 4147-4155.

Li H. J., JiAnG Y. \& Li P. 2006. Chemistry, bioactivity and geographical diversity of steroidal alkaloids from the Liliaceae family. Nat Prod Rep 23: 735-752.

Li H. T., WANG H., YANG J. B. \& Li D. Z. 2011. Genetic diversity of the traditional Chinese medicinal plant Ypsilandra thibetica (Melanthiaceae): Applications for conservation. Biochem Syst Ecol 39: 425-433. http:// dx.doi.org/10.1016/j.bse.2011.06.004

Li W., WANG L., ZhaO D. \& LiU Y. 2012. Steroidal alkaloids from Veratrum nigrum. Chem Nat Compd 48(5): 919-920.

Liao W. J., YuAn Y.M. \& Zhang D. Y. 2007. Biogeography and evolution of flower color in Veratrum (Melanthiaceae) through inference of a phylogeny based on multiple DNA markers. Plant Syst Evol 267: 177-190. http://dx.doi.org/10.1007/s00606-007-0528-z

Llanes A., Bonercarrere V., Capdevielle F., Vidal S. \& LuNA V. 2011. Genetic diversity in a natural population of the halophytic legume Prosopis strombulifera revealed by AFLP fingerprinting. Bol Soc Argent Bot 46: 305-312.

LynCh M. \& Milligan B. G. 1994. Analysis of population genetic structure with RAPD markers. Mol Ecol 3: 91-99. http://dx.doi.org/10.1111/j.1365-294X.1994. tb00109.x

Magdy M., Werner O., McDaniel S. F., Goffinet B. \& Ros R.M. 2016. Genomic scanning using AFLP to detect loci under selection in the moss Funaria hygrometrica along a climate gradient in the Sierra Nevada Mountains, Spain. Plant Biol (Stuttg) 18(2): 280-8. doi: $10.1111 / \mathrm{plb} .12381$

Metin Ö. K., Türktaș M., Aslay M. \& Kaya E. 2013. Evaluation of the genetic relationship between Fritillaria species from Turkey's flora using fluorescent-based AFLP. Turk J Biol 37: 273-279. 
Milligan B. 1992. Plant DNA isolation. In: A. R. Hoelzel (ed.). Molecular genetic analysis of populations: A practical approach, 59-88 pp. IRL Press, Oxford.

Nei M. 1972. Genetic distance between populations. Am Nat 106: 283-292. http://dx.doi.org/10.1086/282771

PAGE R. D. M. 1996. TREEVIEW: An application to display phylogenetic trees on personal computers. Comput Appl Biosci 12: 357-358.

Pompanon F., Bonin A., Bellemain E. \& Taberlet P. 2005. Genotyping errors: causes, consequences and solutions. Nat Rev Genet 6: 847-859.

Pritchard J. K., STePhens M. \& Donnelly P. 2000. Inference of population structure using multilocus genotype data. Genetics 155: 945-959.

Quagliaro G., Vischi M., Tyrka M. \& Olivieri A. M. 2001. Identification of wild and cultivated sunflower for breeding purposes by AFLP markers. J Hered 92: 38-42.

Roldan-Ruiz I., Dendauw J., Van Bockstaele E., Depicker A. \& De Loose M. 2000. AFLP markers reveal high polymorphic rates in rye grasses (Lolium spp.). Mol Breed 6: 125-134.

Sarwat M., Das S. \& Srivastava P. S. 2008. Analysis of genetic diversity through AFLP, SAMPL, ISSR and RAPD markers in Tribulus terrestris, a medicinal herb. Plant Cell Rep 27: 519-528. http://dx.doi.org/10.1007/ s00299-007-0478-5

Schaffner U., Kleijn D., Brown V. \& Müller-Schärer H. 2001. Veratrum album L. in montane grasslands: a model system for implementing biological control in land management practices of high biodiversity habitats. Biocontrol News and Information 22: 19-28.

Tang J., Li H. L., Shen Y. H., Jin H. Z., Yan S. K., Liu R. H. \& ZHANG W. D. 2008a. Antitumor activity of extracts and compounds from the rhizomes of Veratrum dahuricum. Phytother Res 22: 1093-1096. http://dx.doi. org/10.1002/ptr.2463

TANG J., Li H. L., Shen Y. H., Jin H. Z., YAn S. K., Liu R. \& ZhANG W. D. 2008b. Simultaneous Determination of Six Steroidal Alkaloids of Veratrum dahuricum by HPLC-ELSD and HPLC-MS ${ }^{n}$. Chromatographia 67: $15-21$.

TANG T., ZhONG Y., JiAn S. \& SHI S. 2003. Genetic diversity of Hibiscus tiliaceus (Malvaceae) in China assessed using AFLP markers. Ann Bot 92: 409-414.
Thayer S. P., Di Magliano M. P., Heiser P. W., Nielsen C. M., Roberts D. J., Lauwers G. Y., Qi Y. P., Gysin S., Del Castillo C. F., Yajnik V., Antoniu B., McMahon M., Warshaw A. L. \& Hebrok M. 2003. Hedgehog is an early and late mediator of pancreatic cancer tumorigenesis. Nature 425: 851-856. http://dx.doi. org/10.1038/nature02009

Thomas C. M., Vos P., Zabeau M., Jones D. A., Norcott K. A., Chadwick B. P. \& Jones J. D. 1995. Identification of amplified restriction fragment polymorphism (AFLP) markers tightly linked to the tomato Cf-9 gene for resistance to Cladosporium fulvum. Plant J 8: 785-794. http://dx.doi.org/10.1046/j.1365313X.1995.08050785.x

Treier U. A. \& Müller-Schärer H. 2011. Differential effects of historical migration, glaciations, and human impact on the genetic structure and diversity of the mountain pasture weed Veratrum album L. J Biogeogr 38: 1776-1791.

Vekemans X., Beauwens T., Lemaire M. \& Roldan-Ruiz I. 2002. Data from amplified fragment length polymorphism (AFLP) markers show indication of size homoplasy and of a relationship between degree of homoplasy and fragment size. Mol Ecol 11: 139-151. http://dx.doi.org/10.1046/j.09621083.2001.01415.x

Vos P., Hogers R., Bleeker M., Reijans M., van de Lee T., Hornes M., Frijters A., Pot J., Peleman J. \& KUIPER M. 1995. AFLP: a new technique for DNA fingerprinting. Nucleic Acids Res 23: 4407-4414. http://dx.doi.org/10.1093/nar/23.21.4407

Wang L., Zhao D. \& LiU Y. 2008. Quality assessment of Veratrum nigrum L. by LC-ELSD fingerprints and LC quantitative analysis. Chromatographia 68: 961-967. http://dx.doi.org/10.1365/s10337-008-0799-8

Yeh F. C. \& Boyle T. J. B. 1997. Population genetic analysis of co-dominant and dominant markers and quantitative traits. Belg J Bot 129:157.

Zomlefer W. B, Whitten W. M., Williams N. H. \& Judd W. S. 2003. An overview of Veratrum (Liliales: Melanthiaceae) and an infrageneric phylogeny based on ITS sequence data. Syst Bot 28: 250-269. 